\title{
Publisher Correction: Post-translational insertion of boron in proteins to probe and modulate function
}

Tim A. Mollner (D), Patrick G. Isenegger, Brian Josephson, Charles Buchanan, Lukas Lercher, Daniel Oehlrich, D. Flemming Hansen (D), Shabaz Mohammed (D), Andrew J. Baldwin (D), Véronique Gouverneur (D) and Benjamin G. Davis (D)

Correction to: Nature Chemical Biology https://doi.org/10.1038/s41589-021-00883-7, published online 1 November 2021.

In the version of this article initially published, there was a composition error in Fig. 5a where, for the first, fifth and ninth columns correlating to " $T_{\mathrm{ON}}$ Cys" in the key, the pink color dropped out of the columns and top key. The HTML and PDF versions of the article have been corrected online.

Open Access This article is licensed under a Creative Commons Attribution 4.0 International License, which permits use, sharing, adaptation, distribution and
reproduction in any medium or format, as long as you give appropriate credit to the original author(s) and the source, provide a link to the Creative Commons
license, and indicate if changes were made. The images or other third party material in this article are included in the article's Creative Commons license,
unless indicated otherwise in a credit line to the material. If material is not included in the article's Creative Commons license and your intended use is not permitted by statutory
regulation or exceeds the permitted use, you will need to obtain permission directly from the copyright holder. To view a copy of this license, visit http://creativecommons.org/
licenses/by/4.0\%.

Published online: 13 December 2021

https://doi.org/10.1038/s41589-021-00957-6

(c) The Author(s), 2021 